\title{
Peripheral Inflammation Sensitizes P2X Receptor-Mediated Responses in Rat Dorsal Root Ganglion Neurons
}

\author{
Guang-Yin $\mathbf{X u}^{1}$ and Li-Yen Mae Huang ${ }^{1,2}$ \\ ${ }^{1}$ Marine Biomedical Institute and ${ }^{2}$ Department of Physiology and Biophysics, University of Texas Medical Branch, \\ Galveston, Texas 77555-1069
}

\begin{abstract}
ATP-gated P2X receptors in nociceptive sensory neurons participate in transmission of pain signals from the periphery to the spinal cord. To determine the role of P2X receptors under injurious conditions, we examined ATP-evoked responses in dorsal root ganglion (DRG) neurons isolated from rats with peripheral inflammation, induced by injections of complete Freund's adjuvant (CFA) into the hindpaw. Application of ATP induced both fast- and slow-inactivating currents in control and inflamed neurons. CFA treatment had no effect on the affinity of ATP for its receptors or receptor phenotypes. On the other hand, inflammation caused a twofold to threefold increase in
\end{abstract}

both ATP-activated currents, altered the voltage dependence of P2X receptors, and enhanced the expression of P2X2 and P2X3 receptors. The increase in ATP responses gave rise to large depolarizations that exceeded the threshold of action potentials in inflamed DRG neurons. Thus, P2X receptor upregulation could account for neuronal hypersensitivity and contribute to abnormal pain responses associated with inflammatory injuries. These results suggest that $\mathrm{P} 2 \mathrm{X}$ receptors are useful targets for inflammatory pain therapy.

Key words: dorsal root ganglion; ATP; P2X receptor; Western blotting; peripheral inflammation; pain; electrophysiology
In addition to being an intracellular energy source, ATP is released from neuronal and non-neuronal cells, acts on purinergic receptors, and regulates activities of autonomic and sensory neurons, smooth muscle, and endothelial cells (Jahr and Jessell, 1983; Cook and McCleskey, 2000; North and Surprenant, 2000; Burnstock, 2001). In primary sensory dorsal root ganglion (DRG) cells, ATP plays a prominent role in signaling. It depolarizes DRG neurons by eliciting fast- and slow-inactivating inward currents. The fast-inactivating ATP currents are mediated by homomeric $\mathrm{P} 2 \mathrm{X} 3$ receptors; the slow-desensitizing currents are mediated by heteromeric P2X2/3 receptors (Bradbury et al., 1998; Virginio et al., 1998; Burgard et al., 1999; Grubb and Evans, 1999). In addition, ATP modulates synaptic transmission at DRG and dorsal horn synapses (Bardoni et al., 1997; Li et al., 1998). It enhances spontaneous glutamate responses and elicits action potentials to evoke glutamate release (Gu and MacDermott, 1997; Nakatsuka and Gu, 2001). Studies of P2X receptor distributions show that $\mathrm{P} 2 \mathrm{X} 2$ and $\mathrm{P} 2 \mathrm{X} 3$ receptor subtypes are selectively expressed in structures associated with pain signal processing, including small- and medium-sized DRG neurons, peripheral and central sensory terminals, and superficial dorsal horns (Chen et al., 1995; Lewis et al., 1995; Cook et al., 1997; Vulchanova et al., 1998; Kanjhan et al., 1999). Behavioral experiments suggest that applications of the P2X agonists ATP and $\alpha \beta$ meATP to the rat hindpaw decrease the tail-flick latency and produce flinching and writhing behaviors (Cockayne et al., 2000; Souslova et al., 2000; Tsuda et al., 2000). Thus, activation of P2X receptors in sensory

\footnotetext{
Received May 22, 2001; revised Sept. 18, 2001; accepted Oct. 16, 2001.

This work was supported by National Institutes of Health Grant NS 30045 (to L.-Y.M.H.). We thank Dr. C. Wang for advice on Western blotting analyses, Drs. Y. $\mathrm{Gu}$ and R. Coggeshall for comments on this manuscript, and S. Y. Wong for technical assistance.

Correspondence should be addressed to Dr. Li-Yen Mae Huang, Marine Biomedical Institute, University of Texas Medical Branch, 301 University Boulevard, Galveston, TX 77555-1069. E-mail: lmhuang@utmb.edu.

Copyright (C) 2001 Society for Neuroscience $0270-6474 / 01 / 220093-10 \$ 15.00 / 0$
}

neurons facilitates transmission of nociceptive signals from the periphery to the spinal cord.

The consequences of nerve and tissue injuries on ATP responses have not been thoroughly explored. Insults to afferent fibers and peripheral tissues, such as neuropathy and inflammation, frequently give rise to exaggerated responses to non-noxious and noxious stimuli (allodynia and hyperalgesia). These pathological responses are thought to arise from sensitization of DRG and dorsal horn neurons to external stimuli (Woolf and Doubell, 1994; Xu et al., 2000). Stanfa et al. (2000) find that the spinally administered $\mathrm{P} 2 \mathrm{X}$ antagonists suramin and pyridoxalphosphate6-azophenyl-2',4'-disulfonic acid (PPADS) reduce C-fiberevoked discharges in deep dorsal horn neurons of rats with inflammation but have no effect on those in normal or nerveligated rats. Hamilton et al. (1999) show that high concentrations of ATP ( $\geq 100 \mathrm{nmol}$ ) to the hindpaw of normal rats are required to produce nocifensive behaviors (i.e., paw lifting, shaking, and licking) and heat hyperalgesia. However, 1 nmol of ATP can evoke these behaviors in rats inflamed with carrageenan. Furthermore, ATP-evoked activity of C-mechanoheat or polymodal nociceptors is greatly enhanced (Hamilton et al., 2001). P2X receptor activation is therefore facilitated after inflammation. The mechanism underlying the facilitation is unknown. Here we examine the ATP-evoked responses and the expression of P2X receptors in DRG neurons isolated from rats with peripheral inflammation. Our results show that inflammation produces a large increase in $\mathrm{P} 2 \mathrm{X}$ receptor currents.

Parts of this work have been published previously in abstract form (Xu and Huang, 1999).

\section{MATERIALS AND METHODS}

Induction of peripheral inflammation. All experiments were approved by the Institutional Animal Care and Use Committee at the University of Texas Medical Branch and were in accordance with the guidelines of the National Institutes of Health and the International Association for the Study of Pain. Sprague Dawley rats (27-37 d old) were used for the 
studies. Complete Freund's adjuvant (CFA) (Mycobacterium butyricum; Difco, Detroit, MI) emulsion (1:1 peanut oil $/$ saline, $10 \mathrm{mg} / \mathrm{ml}$ Mycobacterium) was injected into the ankle and plantar surface (100 $\mu \mathrm{l}$ each) of the left hindpaw (Gu and Huang, 2001). The injections produced localized inflammation characterized by redness, edema, and hyperalgesia in the hindpaw and ankle.

Dissociation of DRG neurons. Control rats $(n=42)$ and rats 3-14 d after CFA injection $(n=87)$ were killed by cervical dislocation, followed by decapitation. L4-L6 DRGs were then dissected out and put in an ice-cold, oxygenated dissecting solution, containing (in $\mathrm{mM}$ ): $130 \mathrm{NaCl}, 5$ $\mathrm{KCl}, 2 \mathrm{KH}_{2} \mathrm{PO}_{4}, 1.5 \mathrm{CaCl}_{2}, 6 \mathrm{MgCl}_{2}, 10$ glucose, and $10 \mathrm{HEPES}, \mathrm{pH} 7.2$ (osmolarity, $305 \mathrm{mOsm}$ ). After removal of the connective tissue, the ganglia were transferred to a $10 \mathrm{ml}$ dissecting solution containing collagenase IV (1.0-1.5 mg/ml; Boehringer Mannheim, Indianapolis, IN) and trypsin $(1.0 \mathrm{mg} / \mathrm{ml}$; Sigma, St. Louis, MO) and incubated for $1 \mathrm{hr}$ at $34.5^{\circ} \mathrm{C}$. DRGs were then taken from the enzyme solution, washed, and put in $3 \mathrm{ml}$ of the dissecting solution containing DNase $(0.5 \mathrm{mg} / \mathrm{ml}$; Sigma). Cells were subsequently dissociated by trituration with firepolished glass pipettes and placed on acid-cleaned glass coverslips.

Perforated patch recording and application of drugs. Cells were superfused $(2 \mathrm{ml} / \mathrm{min})$ at room temperature with an external solution containing (in mM): $130 \mathrm{NaCl}, 5 \mathrm{KCl}, 2 \mathrm{KH}_{2} \mathrm{PO}_{4}, 2.5 \mathrm{CaCl}_{2}, 1 \mathrm{MgCl}_{2}, 10$ HEPES, and 10 glucose, pH 7.2 (osmolarity, 295-300 mOsm). ATPinduced currents and action potentials were recorded using the perforated patch-clamp technique. The patch electrode had a resistance between 2.2 and $3.5 \mathrm{M} \Omega$. The pipette tip was initially filled with amphotericin-free pipette solution, containing (in mM): $100 \mathrm{KmeSO}_{3}, 40$ $\mathrm{KCl}$, and 10 HEPES, pH 7.25 adjusted with $\mathrm{KOH}$ (osmolarity, 290 mOsm). The pipette was then backfilled with same pipette solution containing amphotericin B $(300 \mu \mathrm{g} / \mathrm{ml})$. The currents were filtered at 2-5 $\mathrm{kHz}$ and sampled at 50 or $100 \mu \mathrm{sec}$ per point.

All chemicals were pressure delivered (1-2 psi) to the recorded cell through two applicators (Dilger and Brett, 1990). Each applicator was connected to a solenoid valve, which was controlled by computer pulses to start and stop the solution flow. To determine the rate of solution exchange, a depolarized pulse to $-10 \mathrm{mV}$ was used to activate a delayed rectifying $\mathrm{K}^{+}$current in DRG neurons. When the current reached a steady state, the external $\mathrm{KCl}$ concentration was switched from 5 to 30 mM. This resulted in a change in $\mathrm{K}^{+}$currents. The time constant for the current change through the open $\mathrm{K}^{+}$channels, an indicator of the solution exchange rate, was $2.0 \mathrm{msec}$. The exchange rate was fast and would not limit peak ATP responses. ATP, $\alpha \beta$ meATP, suramin, PPADS, and TTX were purchased from Sigma, and $2^{\prime}, 3^{\prime}-O-\left(2^{\prime}, 4^{\prime}, 6^{\prime}\right)$-trinitrophenylATP (TNP-ATP) was from Molecular Probes (Eugene, OR).

Western blotting. L4-L6 DRGs from control rats or the DRGs ipsilateral to the CFA-injected paw of CFA-treated rats were dissected out and lyzed in $100 \mu \mathrm{l}$ of radioimmunoprecipitation assay buffer containing $1 \%$ NP-40, $0.5 \%$ Na deoxycholate, $0.1 \%$ SDS, PMSF $(10 \mu \mathrm{l} / \mathrm{ml})$, and aproti$\operatorname{nin}(30 \mu \mathrm{l} / \mathrm{ml}$; Sigma). The cell lysates were then microf uged at $15,000 \times$ $g$ for $25 \mathrm{~min}$ at $4^{\circ} \mathrm{C}$. The concentration of protein in homogenate was determined using a BCA reagent (Pierce, Rockford, IL). Ten micrograms of proteins for $\mathrm{P} 2 \mathrm{X} 1$ and $\mathrm{P} 2 \mathrm{X} 2$ studies or $5 \mu \mathrm{g}$ of proteins for P2X3 studies were loaded onto a $10 \%$ Tris-HCl SDS-PAGE gel (BioRad, Hercules, CA). After electrophoresis, the proteins were electrotransferred onto polyvinylidene difluoride membranes (Bio-Rad) overnight at $4^{\circ} \mathrm{C}$. The membranes were incubated in $25 \mathrm{ml}$ of blocking buffer (1× TBS with $5 \% \mathrm{w} / \mathrm{v}$ fat-free dry milk) for $2 \mathrm{hr}$ at room temperature. The membranes were then incubated with the primary antibodies for 1.5 $\mathrm{hr}$ at room temperature. Primary antibodies used were rabbit anti-P2X3 (1:3000; Neuromics Inc., Minneapolis, MN), rabbit anti-P2X1 and-P2X2 (1:200; Alomone Labs, Jerusalem, Israel), and mouse anti-actin (1:1000; Chemicon, Temecula, CA). After incubation, the membranes were washed with TBST $(1 \times$ TBS and $1 \%$ Tween 20) three times for $30 \mathrm{~min}$ each and incubated with anti-rabbit peroxidase-conjugated secondary antibody (1: 2000; Santa Cruz Biotechnology, Santa Cruz, CA) or antimouse HRP-conjugated secondary antibody (1:400; Chemicon) for $1 \mathrm{hr}$ at room temperature. The membrane was then washed with TBST three times for $30 \mathrm{~min}$ each. The immunoreactive proteins were detected by enhanced chemiluminescence (ECL kit; Amersham Biosciences, Arlington Heights, IL). The bands recognized by primary antibody were visualized by exposure of the membrane onto an x-ray film.

Data analyses. Rise times $\left(T_{\mathrm{a}}\right)$ of ATP responses were obtained by measuring the activation time between 10 and $90 \%$ of the peak value. The time constants of current inactivation $\left(\tau_{\text {in }}\right)$ were obtained by fitting the decay phase of the currents with exponential functions using the Levenberg-Marquardt algorithm.

Membrane conductance $(G)$ at each holding potential $(V)$ was calculated according to the equation $G=I /\left(V-V_{\text {rev }}\right)$, where $I$ is the ATP current, and $V_{\text {rev }}$ is the reversal potential. The $G-V$ curve was fitted with the Boltzmann equation $G=G_{\max } /(1+\exp (A))$, where $A=\left(V-V_{0.5}\right) *(\mathrm{ZFV} / \mathrm{RT}) . G_{\max }$ is the maximal conductance, $V_{0.5}$ is the potential at which $G / G_{\max }=0.5, V$ is the membrane potential, $R$ is the gas constant, $T$ is the absolute temperature, $Z$ is the charge factor, and $F$ is the Faraday constant.

Dose-response curves for ATP activation were fit with the Hill equation $I=I_{\max } *\left([\mathrm{ATP}]^{n}\right) /\left([\mathrm{ATP}]^{n}+\left(\mathrm{EC}_{50}\right)^{n}\right)$, where $I$ is the measured current, $I_{\max }$ is the maximal response, $\mathrm{EC}_{50}$ is the ATP concentration used to obtain $50 \%$ of the maximal response, and $n$ is the Hill coefficient.

Data are expressed as mean \pm SEM or as percentage. Student's $t$ or $\chi^{2}$ test was used to assess the significance of changes after CFA treatment. $p<0.05$ was considered significant.

\section{RESULTS}

\section{Potentiation of ATP-activated currents after inflammation}

To determine the effect of inflammation on ATP-activated currents, the properties of the currents in neurons from control and CFA-treated rats were examined under voltage-clamp conditions. Peripheral inflammation was induced by injecting CFA into the ankle and plantar surface of the rat left hindpaw. L4-L6 DRGs were isolated 3-14 d after the CFA injection, a period of peak hyperalgesic conditions. We chose small to medium diameter (15-40 $\mu \mathrm{m})$ DRG neurons for the study because they mediate transmission of nociceptive signals (Willis and Coggeshall, 1991).

Applications of ATP $(20 \mu \mathrm{M})$ evoked large inward currents at $-60 \mathrm{mV}$ holding potential in control DRG neurons. Based on the time course of the responses, they were categorized as fast, slow, and mixed responses. The fast ATP-evoked currents were rapidly activating and inactivating (Fig. $1 A$ ). The rise times of the fast responses were short $\left(T_{\mathrm{a}}=6.5 \pm 1.1 \mathrm{msec} ; n=18\right)$. The currents reduced to $<5.0 \pm 0.5 \%$ of their peak amplitudes within $2 \mathrm{sec}$ of ATP applications. The inactivating phase of the currents was best fitted with a sum of two exponentals $\left(\tau_{1 \text { in }}=38.1 \pm 7.7 \mathrm{msec}\right.$, $A_{1}=605.3 \pm 171.2 \mathrm{pA}, \tau_{2 \text { in }}=477.3 \pm 177.2 \mathrm{msec}, A_{2}=120.2 \pm$ $20.6 \mathrm{pA} ; n=11)$. Once inactivated, the fast ATP responses recovered very slowly. The original peak amplitude would not be restored unless there was a $10-15$ min wait between consecutive ATP applications.

The slow ATP responses in control neurons were characterized by relatively slow rise times $\left(T_{\mathrm{a}}=38.5 \pm 5.97 \mathrm{msec} ; n=10\right)$. The inactivation kinetics varied among cells. In a small percentage $(\sim 8 \%)$ of cells, slow ATP responses showed very little inactivation during the ATP application. A majority of slow responses, however, showed inactivation. The decay kinetics could be fit with one exponential. The average inactivation time constant $\left(\tau_{\text {in }}\right)$ was $2007.5 \pm 200.4 \mathrm{msec}(n=10)$, which was $\sim 4-50$ times slower than those of the fast ATP responses. Unlike the fast ATP responses, the slow ATP responses recovered rather quickly. The peak response returned to its original size within 1 min after an ATP application.

ATP also evoked inward currents in a large number of neurons isolated from CFA rats. Similar to control cells, ATP evoked fast and slow responses in inflamed neurons. The most prominent change was the large enhancement of current amplitudes (Fig. $1 B)$. The average peak current density of the fast responses in inflamed neurons was 2.7-fold larger (control, $0.30 \pm 0.05 \mathrm{pA} /$ $\left.\mu \mathrm{m}^{2}, n=29 ; \mathrm{CFA}, 0.82 \pm 0.13 \mathrm{pA} / \mu \mathrm{m}^{2}, n=48\right)$. The kinetic characteristics of the fast ATP responses of inflamed neurons were similar to those obtained from control neurons (Table 1). 
$\mathbf{A}$

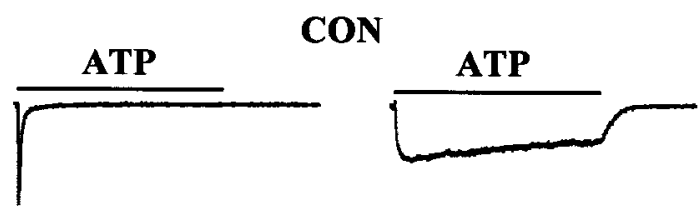

B
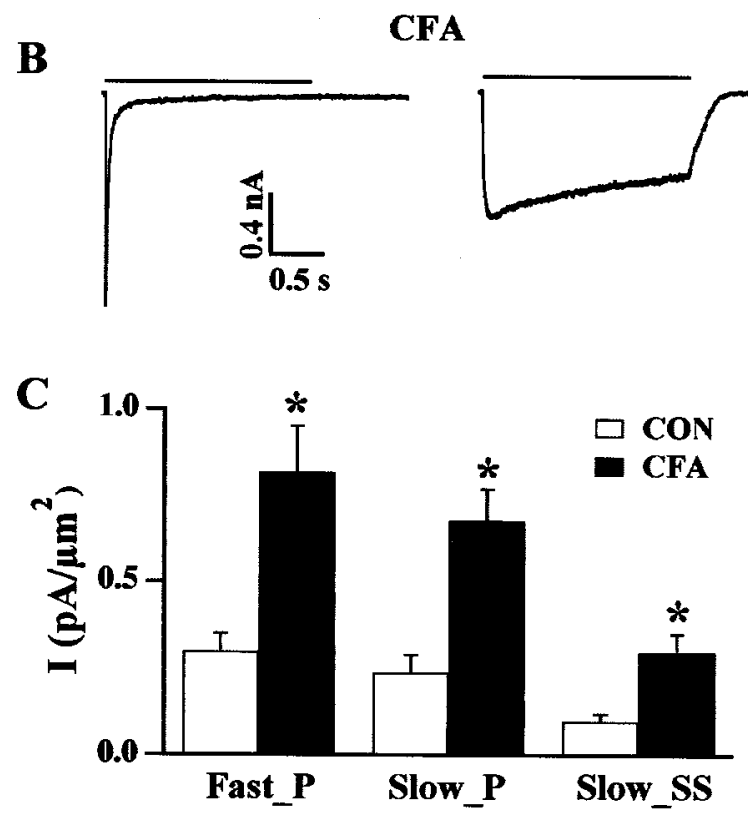

Figure 1. Inflammation potentiates ATP-activated currents. $A$, Examples of currents evoked by ATP application in control rats $(C O N)$. ATP $(20 \mu \mathrm{M})$ activated fast-inactivating (left) and slow-inactivating (right) currents in DRG neurons. The membrane was held at $-60 \mathrm{mV}$. Results were obtained from two different cells. The solid line above each trace indicates the period of ATP application. B, Examples of currents evoked by ATP application in rats injected with CFA. Under similar conditions as in $A$, ATP also evoked fast-inactivating (left) and slow-inactivating (right) currents in DRG cells. The amplitudes of both types of currents were much larger than those obtained in control rats. $C$, Mean fast and slow current densities from control and CFA rats. The mean peak fastinactivating $($ Fast_P $)$ current density measured in CFA rats was 2.7 times larger than that measured in control rats (Fast P: control, $0.30 \pm 0.05$ $\mathrm{pA} / \mu \mathrm{m}^{2}, n=29$; CFA, $\left.0.82 \pm 0.13 \mathrm{pA} / \mu \mathrm{m}^{2}, n=48 ; * p<0.01\right)$. The mean peak slow-inactivating (Slow_ $P$ ) current density in CFA rats was 2.8 times larger (Slow_P: control, $0.24 \pm 0.05 \mathrm{pA} / \mu \mathrm{m}^{2}, n=25$; CFA, $0.68 \pm$ $0.09 \mathrm{pA} / \mu \mathrm{m}^{2}, n=38$ ), and the mean steady-state slow (Slow_SS) current density was 3.0 times larger than those obtained in control rats (Slow_SS: control, $0.10 \pm 0.02 \mathrm{pA} / \mu \mathrm{m}^{2}, n=25 ; \mathrm{CFA}, 0.30 \pm 0.05 \mathrm{pA} / \mu \mathrm{m}^{2}, n=38$; $\left.{ }^{*} p<0.01\right)$.

The fast ATP responses in inflamed neurons activated rapidly $\left(T_{\mathrm{a}}=6.3 \pm 0.78 \mathrm{msec}, n=19\right)$ and desensitized in two phases $\left(\tau_{1 \text { in }}=49.4 \pm 7.9 \mathrm{msec}, A_{1}=1352.7 \pm 237.1 \mathrm{pA} ; \tau_{2 \text { in }}=292.7 \pm\right.$ $\left.30.4 \mathrm{msec}, A_{2}=325.5 \pm 58.4 \mathrm{pA} ; n=19\right)$. The currents were desensitized completely during the 2 sec ATP application.

ATP also evoked slow responses in inflamed neurons. The amplitudes of slow responses were also greatly potentiated. The average peak current density of the slow-inactivating currents was increased by 2.8-fold (control, peak $0.24 \pm 0.05 \mathrm{pA} / \mu \mathrm{m}^{2}, n=25$; CFA, peak $0.68 \pm 0.09 \mathrm{pA} / \mu \mathrm{m}^{2}, n=38$ ); the average steady-state current density of the slow responses was increased by 3.0 -fold (control, $0.10 \pm 0.02 \mathrm{pA} / \mu \mathrm{m}^{2}, n=25$; CFA, $0.30 \pm 0.05 \mathrm{pA} / \mu \mathrm{m}^{2}$, $n=38$ ) (Fig. 1C). The kinetic properties of slow responses in inflamed neurons were not significantly different from those of control neurons (Table 1$)$. The slow ATP responses of inflamed neurons had a mean rise time $\left(T_{\mathrm{a}}\right)$ of $52.0 \pm 8.2 \mathrm{msec}(n=16)$, and a mean decayed time constant of $\tau_{\text {in }}=2318.4 \pm 379.5 \mathrm{msec}$ $(n=16)$.

We also observed ATP currents with mixed fast and slow characteristics in both control and inflamed (data not shown). Like the fast ATP responses, the mixed ATP responses were characterized by a fast rise time and a distinct two-phase inactivation. The fast inactivation phase had a time constant similar to the $\tau_{1 \text { in }}$ of the fast ATP responses. However, the slow inactivation phase had a time constant that was much slower than the $\tau_{2 \text { in }}$ of the fast ATP responses. Thus, a substantial portion of the current remained at the end of the 2 sec ATP application, a characteristic feature of the slow ATP responses. To simplify our analyses, the mixed ATP responses, which occurred in $8.5 \%$ of ATP responding control neurons (12 of 141 cells tested) and $11.6 \%$ of responding CFA neurons (32 of 276 cells), were not included in this study.

\section{Cell distribution of ATP responses}

We then analyzed the cell types that displayed either fast or slow ATP responses. ATP-induced responses were observed in $89.4 \%$ of all recorded DRG neurons $(n=141)$ isolated from control rats and in $93.8 \%$ of DRG neurons $(n=276)$ isolated from CFAinjected rats. Thus, the percentages of neurons responding to ATP remained unchanged after CFA treatment $(p>0.05)$. Analyses of the types of ATP responses in control neurons indicated that $33.3 \%$ of recorded neurons $(n=47)$ exhibited fast-inactivating ATP currents, and $47.5 \%$ of cells exhibited slowinactivating ATP currents $(n=67)$. After inflammation, $42.8 \%$ of neurons $(n=118)$ exhibited fast ATP responses, and $39.5 \%$ of cells $(n=109)$ exhibited slow ATP responses. Therefore, two types of responses occurred with approximately equal frequencies in control and CFA-treated rats $(p>0.05)$ (Fig. 2A).

Cell size distribution of fast- and slow-inactivating ATP responses was also obtained using cumulative distribution analyses. The percentages of cells exhibiting ATP responses versus cell diameters smaller than the indicated values were plotted (Fig. $2 B$ ). We found that $50 \%$ of cells responding to ATP with fastinactivating currents had diameters $<26 \mu \mathrm{m}$ in both control and CFA rat groups. Cells responding to ATP with slow-inactivating currents for both rat groups were significantly larger (i.e., $50 \%$ of cells responding with slow currents had diameters $<33 \mu \mathrm{m}$ in control rats and $<31 \mu \mathrm{m}$ in CFA rats). Because the cell size distributions for both ATP responses are the same for normal and inflamed rats, inflammation does not appear to alter the types of DRG cells expressed P2X receptors.

\section{P2X receptor phenotypes}

ATP activates more than one subtype of $\mathrm{P} 2 \mathrm{X}$ receptors in control DRG neurons (Vulchanova et al., 1997; North and Surprenant, 2000). It is of interest to determine whether the same P2X receptor subtypes are expressed in DRGs after inflammation. Antagonists were first used to identify P2X receptors in DRGs. Suramin $(30 \mu \mathrm{M})$ and PPADS $(50 \mu \mathrm{M})$ completely blocked fast and slow ATP-evoked currents in control $(n=20)$ and inflamed $(n=25)$ neurons (Fig. $3 A$, left and middle). These two antagonists, at tens of micromolar concentrations, are known to block homomeric P2X1, P2X2, P2X3, and P2X5 and heteromeric $\mathrm{P} 2 \mathrm{X} 2 / 3$ receptors without significantly affecting homomeric P2X4, P2X6, and P2X7 receptors (North and Barnard, 1997; North and Surprenant, 2000). Thus, P2X4, P2X6, and P2X7 were not present in either control or inflamed DRGs. We then used the antagonist TNP-ATP to determine whether homomeric P2X2 receptors were present in our DRG neurons (Fig. 3A, right). 
Table 1. Kinetics of ATP-induced fast and slow currents in dorsal root ganglion neurons isolated from control (CON) and CFA-treated rats

\begin{tabular}{|c|c|c|c|c|c|}
\hline & \multicolumn{3}{|l|}{ Fast } & \multicolumn{2}{|l|}{ Slow } \\
\hline & $T_{\mathrm{a}}$ & $\tau_{1 \text { in }}$ & $\tau_{2 \text { in }}$ & $T_{\mathrm{a}}$ & $\tau_{\text {in }}$ \\
\hline $\mathrm{CON}$ & $\begin{array}{l}6.1 \pm 1.1 \\
(n=18)\end{array}$ & $\begin{array}{l}38.1 \pm 7.7 \\
(n=11)\end{array}$ & $\begin{array}{l}477.3 \pm 177.2 \\
(n=11)\end{array}$ & $\begin{array}{l}38.5 \pm 6.0 \\
(n=10)\end{array}$ & $\begin{array}{l}2007.5 \pm 200.4 \\
(n=10)\end{array}$ \\
\hline CFA & $\begin{array}{l}6.3 \pm 0.8 \\
(n=19)\end{array}$ & $\begin{array}{l}49.4 \pm 7.9 \\
(n=19)\end{array}$ & $\begin{array}{l}292.7 \pm 30.4 \\
(n=19)\end{array}$ & $\begin{array}{l}52.0 \pm 8.2 \\
(n=16)\end{array}$ & $\begin{array}{l}2318.4 \pm 379.5 \\
(n=16)\end{array}$ \\
\hline
\end{tabular}

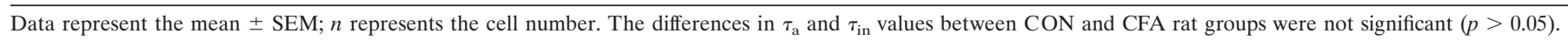
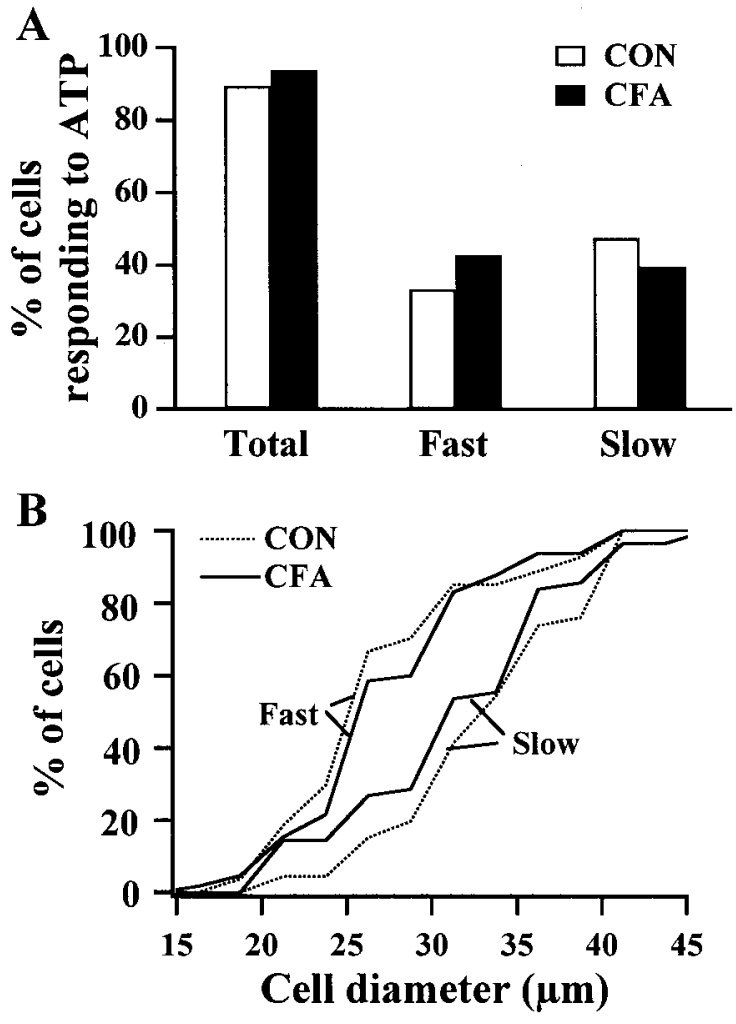

Figure 2. Inflammation does not change the percentages and the size distributions of neurons responding to ATP. A, Percentages of responding cells. The percentage of the total number of cells (Total) responding to ATP was $89.4 \%(n=141)$ in control rats $(C O N)$ and $93.8 \%(n=276)$ in CFA rats. The change was not significant $\left(\chi^{2}\right.$ test; $\left.p>0.05\right)$. The percentages of cells with fast-inactivating ATP responses (Fast) (control, $33.3 \%, n=47$; CFA, $42.8 \%, n=118)$ and the percentages of cells with slow-inactivating ATP responses (Slow) (control, 47.5\%, $n=67$; CFA, $39.5 \%, n=109$ ) were not altered by inflammation. $B$, Cell size distributions for ATP responses. Distributions of cell diameter were expressed in cumulative histograms, i.e., percentages of cells that responded with either fast or slow ATP responses versus cell diameters that were smaller than the indicated values. In control rats, $50 \%$ of cells responding to ATP with fast-inactivating currents ( 13 of 27 cells tested) had diameters $<26$ $\mu \mathrm{m} ; 50 \%$ of the cells responding to ATP with slow-inactivating currents ( 23 of 46 cells tested) had diameters $<33 \mu \mathrm{m}$. The size difference was significant ( $p<0.05$; Kolmogorov-Smirnov test). In CFA rats, $50 \%$ of the cells responding to ATP with fast-inactivating currents had diameters $<26 \mu \mathrm{m}$ (32 of 65 cells tested); $50 \%$ of the cells responding to ATP with slow-inactivating currents had diameters $<31 \mu \mathrm{m}$ ( 28 of 56 cells tested). CFA treatment did not change the size distribution of cells responding to ATP with either the fast- or slow-inactivating currents.

TNP-ATP is 500-fold more sensitive to homomeric P2X1 and $\mathrm{P} 2 \mathrm{X} 3$ and heteromeric $\mathrm{P} 2 \mathrm{X} 2 / 3$ receptors than to homomeric $\mathrm{P} 2 \mathrm{X} 2$ receptors (Thomas et al., 1998). High concentrations $(\geq 1$ $\mu \mathrm{M})$ of TNP-ATP should block P2X1, P2X3, and P2X2/3 receptor-mediated responses but leaves most homomeric P2X2 receptor-mediated responses intact (Thomas et al., 1998; Virginio et al., 1998; North and Surprenant, 2000). At $1 \mu \mathrm{M}$, TNP-ATP blocked all fast ATP currents and reduced slow ATP currents by $98 \%$ in control $(n=18)$ and inflamed $(n=24)$ neurons (Fig. $3 A$, right). Thus, the responses mediated by homomeric $\mathrm{P} 2 \mathrm{X} 2$ receptors, if present in our cells, would be small.

We then used the $\mathrm{P} 2 \mathrm{X}$ receptor agonist $\alpha \beta$ meATP to further identify $\mathrm{P} 2 \mathrm{X}$ receptor types in control and inflamed neurons. Unlike ATP, $\alpha \beta$ meATP has low affinity for homomeric P2X2 and P2X5 receptors (North and Surprenant, 2000). If P2X2 and/or $\mathrm{P} 2 \mathrm{X} 5$ receptors were present in significant quantities, a saturated concentration of ATP $(100 \mu \mathrm{M})$ or $\alpha \beta$ meATP $(100 \mu \mathrm{M})$ should evoke different responses. This was not observed. ATP and $\alpha \beta$ meATP activated currents of similar amplitudes in control $(n=9)$ and inflamed $(n=12)$ neurons (Fig. $3 B)$. Homomeric $\mathrm{P} 2 \mathrm{X} 2$ and $\mathrm{P} 2 \mathrm{X} 5$ receptors, therefore, were not present in sufficient amount to contribute to ATP responses in either control or inflamed DRGs. The expression of P2X1 receptor in control and inflamed neurons has not been studied in detail. Preliminary Western blot analyses showed that the P2X1 receptor immunoreactivity was low in both control and inflamed neurons, suggesting that P2X1 was not the major receptor type in DRGs (data not shown). From these experiments, we conclude that homomeric $\mathrm{P} 2 \mathrm{X} 3$ and heteromeric $\mathrm{P} 2 \mathrm{X} 2 / 3$ receptors are the main receptor types in inflamed DRGs and that inflammation does not elicit significant changes in $\mathrm{P} 2 \mathrm{X}$ receptor phenotypes.

\section{Affinity of ATP for P2X receptors}

To determine whether the increase in ATP responses in inflamed neurons arises from changes in the affinity of ATP for P2X receptors, dose-response curves for ATP in control and inflamed rat groups were studied (Fig. 4). ATP, at $\geq 100 \mu \mathrm{M}$, elicited both maximal fast and slow ATP responses. The maximal fast response was 2.5-fold larger and the maximal slow response was 2.3-fold larger in inflamed neurons. Dose-response curves for both fast and slow ATP responses were fit with the Hill equation. The $\mathrm{EC}_{50}$ for fast ATP responses was $1.7 \pm 0.9 \mu \mathrm{M}$ in control and $2.0 \pm 0.69$ $\mu \mathrm{M}$ in inflamed neurons (Fig. $4 A$ ). The $\mathrm{EC}_{50}$ for slow ATP responses was $5.7 \pm 1.4 \mu \mathrm{M}$ in control and $3.6 \pm 1.2 \mu \mathrm{M}$ in inflamed neurons (Fig. 4B). The changes in ATP affinities for $\mathrm{P} 2 \mathrm{X}$ receptors in inflamed DRG neurons were not significant.

\section{Leftward shift of conductance-voltage curves}

The voltage dependence of ATP responses was also determined. Currents in response to ATP applications were measured at different holding potentials. The peak currents versus voltage $(I-V)$ curves were plotted. Both fast and slow ATP currents reversed at near $+10 \mathrm{mV}$ in control cells (Fig. 5A), and CFA treatment did not change the reversal potentials of ATP re- 
A CFA

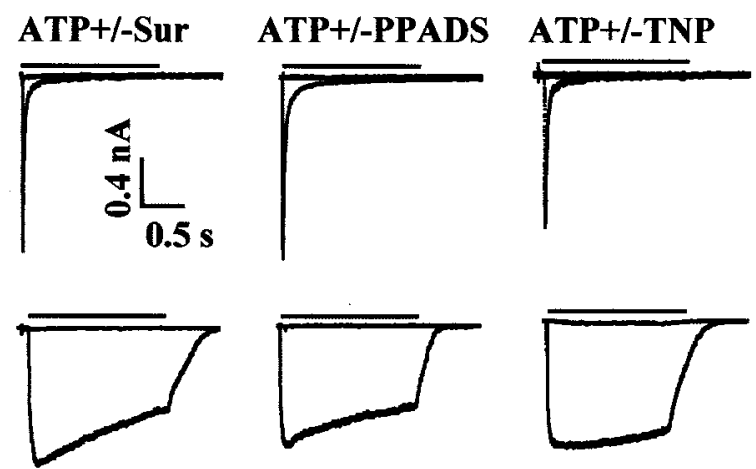

B

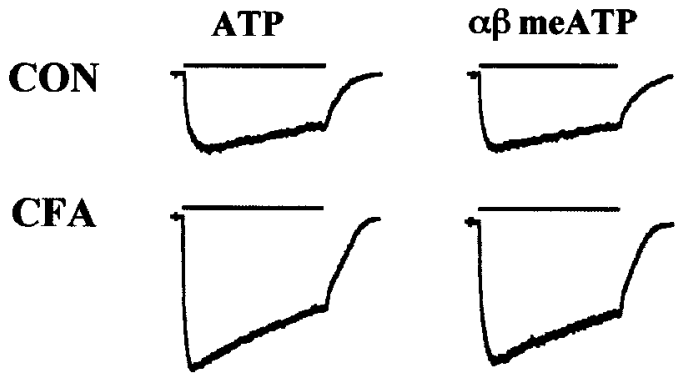

Figure 3. Inflammation does not change the receptor phenotypes. $A$, Effects of $\mathrm{P} 2 \mathrm{X}$ receptor antagonists. In inflamed neurons, the antagonists of P2X receptors suramin $($ Sur; $30 \mu \mathrm{M})$ and PPADS $(50 \mu \mathrm{M})$ completely blocked both fast- and slow-inactivating currents. TNP-ATP $(1 \mu \mathrm{M})$ inhibited the fast ATP responses completely and inhibited the slow ATP responses by $98 \%$. Current traces obtained from ATP plus and minus an antagonist were superimposed. $B$, Effects of the $\mathrm{P} 2 \mathrm{X}$ receptor agonist $\alpha \beta$ meATP. At saturated concentrations, ATP $(100 \mu \mathrm{M})$ and $\alpha \beta$ meATP $(100 \mu \mathrm{M})$ elicited similar responses, suggesting minimal contributions of homomeric P2X2, P2X5 receptor-mediated responses to the observed currents. CFA treatment did not alter the effect of $\alpha \beta$ meATP. CON, Control.

sponses (Fig. 5). Therefore, inflammation had no significant effect on the permeation properties of $\mathrm{P} 2 \mathrm{X} 3$ and $\mathrm{P} 2 \mathrm{X} 2 / 3$ receptors.

Both fast- and slow-inactivating ATP currents showed inward rectification (Fig. 5). The conductance-voltage $(G-V)$ relationships of both types of currents were fit with the Boltzmann equation (Fig. 6). The $G-V$ curves obtained for the fast ATP responses in control neurons had a $Z=0.97 \pm 0.07, G_{\max }=4.4 \pm$ $0.7 \mathrm{pS} / \mu \mathrm{m}^{2}$, and $V_{0.5}=-35.6 \pm 2.9 \mathrm{mV}(n=10)$. CFA treatment did not significantly change the $Z(0.91 \pm 0.08 ; n=12)$ of the $G-V$ curve. As expected from the current data (Fig. 1), the $G_{\max }$ of inflamed neurons was 2.9-fold larger, i.e., $G_{\max }=12.9 \pm 1.4$ $\mathrm{pS} / \mu \mathrm{m}^{2}(n=12)$. Furthermore, the $V_{0.5}$ shifted significantly in the hyperpolarized direction (Fig. 6) $\left(V_{0.5}=-49.5 \pm 2.3 \mathrm{mV}\right.$; $n=12)$.

The $G-V$ of the slow-inactivating ATP currents in control neurons had a $Z=0.92 \pm 0.09, G_{\max }=5.0 \pm 0.9 \mathrm{pS} / \mu \mathrm{m}^{2}$, and $V_{0.5}=-25.0 \pm 4.8 \mathrm{mV}(n=6)$. Compared with the fast ATP currents, the slow ATP responses inactivated at a more depolarized potential. Inflammation did not affect $Z(0.95 \pm 0.06 ; n=$ $12)$, but it increased the $G_{\max }\left(11.0 \pm 1.4 \mathrm{pS} / \mu \mathrm{m}^{2} ; n=12\right)$ of slow ATP responses by 2.2 -fold and shifted $G-V$ curves in the hyperpolarized direction $\left(V_{0.5}=-43.5 \pm 2.8 \mathrm{mV} ; n=12\right)$. Thus, in addition to increasing the maximal conductances, inflammation
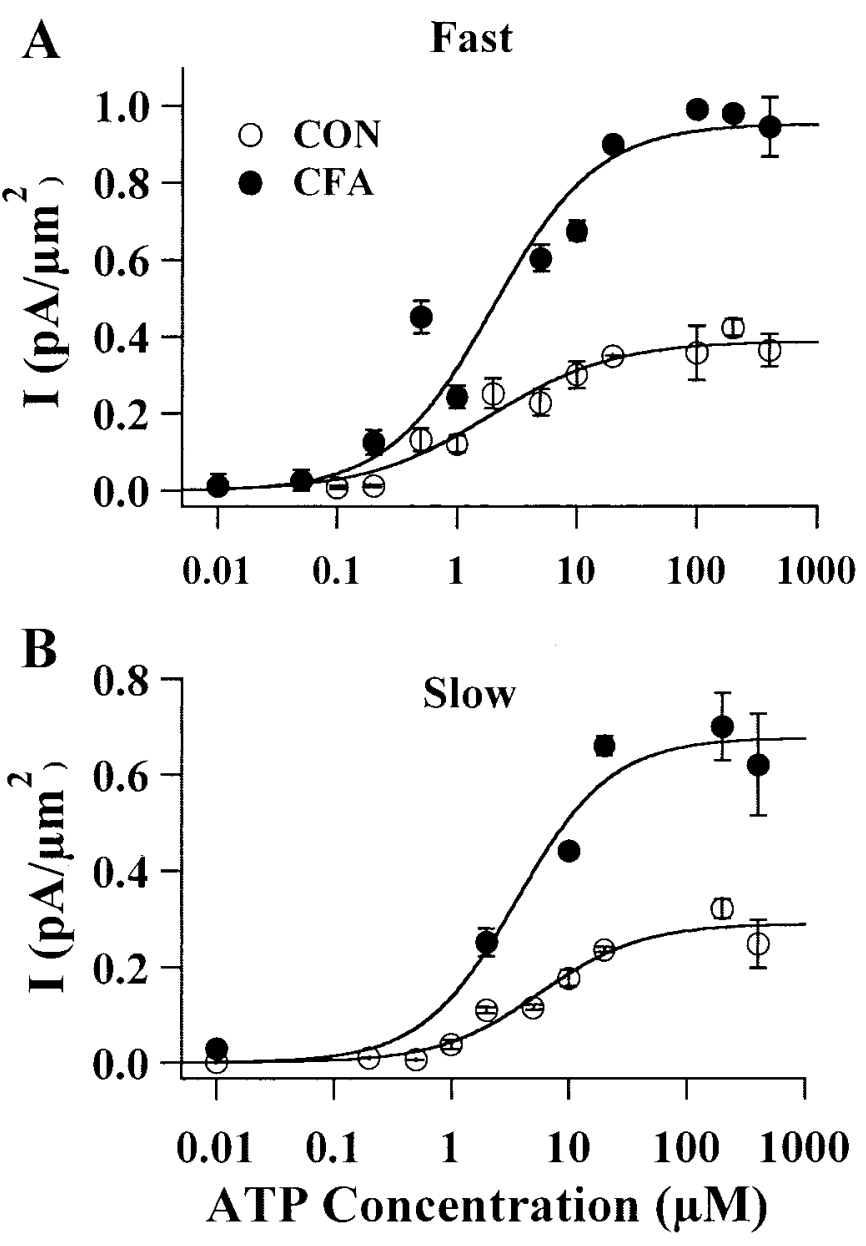

Figure 4. CFA treatment has no effect on the affinity of ATP for P2X receptors. $A$, Dose-response curves for ATP-evoked fast responses. The peak fast-inactivating ATP responses evoked in control and inflamed neurons were plotted as a function of ATP concentration. The doseresponse curves were fit by the Hill equation. For control cells $(C O N)$, $I_{\max }=0.38 \pm 0.04 \mathrm{pA} / \mu \mathrm{m}^{2}, \mathrm{EC}_{50}=1.70 \pm 0.90 \mu \mathrm{M}$, and Hill coefficient $=$ 1. For inflamed cells, $I_{\max }=0.95 \pm 0.06 \mathrm{pA} / \mu \mathrm{m}^{2}, \mathrm{EC}_{50}=2.00 \pm 0.69 \mu \mathrm{M}$, and Hill coefficient $=1$. The data points were obtained from 3-18 cells. $B$, Dose-response curves for ATP-evoked slow responses. For control cells, $I_{\max }=0.29 \pm 0.02 \mathrm{pA} / \mu \mathrm{m}^{2}, \mathrm{EC}_{50}=5.70 \pm 1.40 \mu \mathrm{M}$, and Hill coefficient $=$ 1 . For inflamed cells, $I_{\max }=0.68 \pm 0.14 \mathrm{pA} / \mu \mathrm{m}^{2}, \mathrm{EC}_{50}=3.60 \pm 1.20 \mu \mathrm{M}$, and Hill coefficient $=1$. The data points were obtained from two to eight cells. Therefore, inflammation did not alter the ATP affinities for P2X receptors, although it greatly enhanced the maximal ATP responses.

causes both types of ATP responses to inactivate at more hyperpolarized potentials.

\section{Increased membrane depolarization}

We then compared the effect of ATP on the membrane depolarization of DRG neurons in control and CFA neurons under current-clamp conditions. The average resting membrane potential of DRG neurons recorded from CFA-treated rats was $-49.9 \pm 0.7 \mathrm{mV}(n=104)$, which was not significantly different from the resting membrane potential of neurons recorded from control rats $(-50.8 \pm 1.2 \mathrm{mV} ; n=54)$. In control rats, application of ATP $(20 \mu \mathrm{M})$ produced depolarizations of membrane potentials in 18 of 22 cells tested (Fig. $7 A$ ). Most of the depolarizations were subthreshold (Fig. 7A,B, top left). After CFA treatment, ATP induced depolarization in 30 of 34 neurons. All of the depolarizations were large enough to evoke action potentials 
A

CON
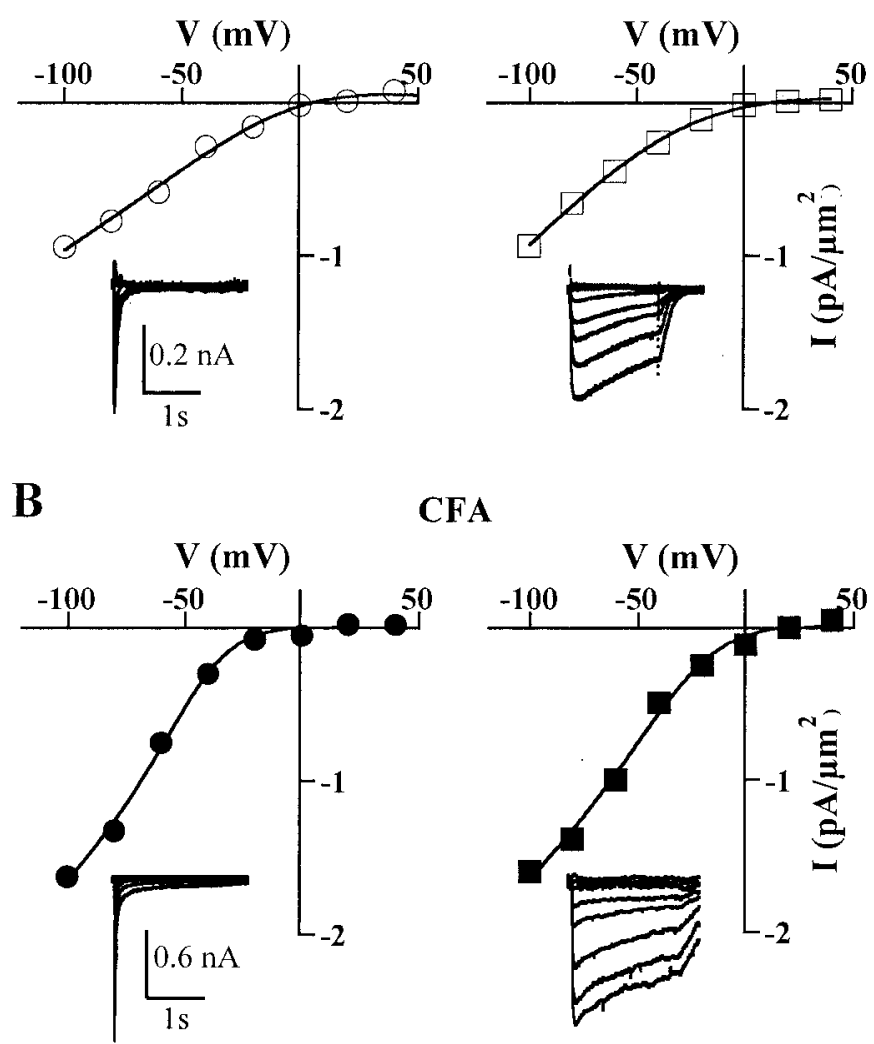

CFA

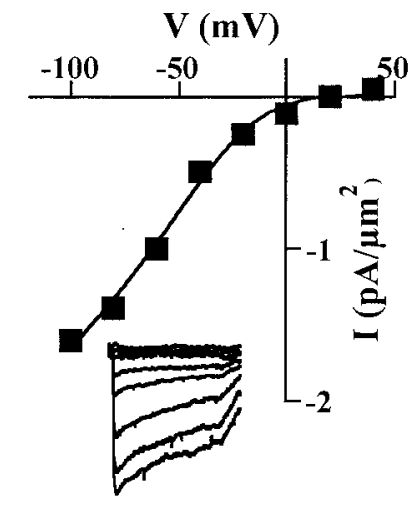

Figure 5. ATP currents in control and inflamed neurons exhibit steep voltage dependence. Examples of current-voltage $(I-V)$ relationships of peak fast (left) and slow (right) ATP currents in control $(C O N)(A)$ and CFA $(B)$ neurons. The currents were measured at different holding potentials. The current traces were shown in the inset of each $I-V$ curve. The reversal potentials of the currents did not change after CFA treatment. Data were obtained from four different cells.

(Fig. 7A,B, bottom right). Because $\mathrm{Na}^{+}$channels are upregulated in the inflammatory state (Gould et al., 1998; Gold, 1999) and could affect changes in the firing properties of inflamed neurons, their contribution to the depolarization has to be eliminated. We therefore isolated the depolarization attributable to $\mathrm{P} 2 \mathrm{X}$ receptor activation by using TTX to block TTX-sensitive $\mathrm{Na}^{+}$channels and a depolarized prepulse to inactivate both TTX-sensitive and -resistant $\mathrm{Na}^{+}$channels (Ogata and Tatebayashi, 1993; Rush et al., 1998). TTX $(2 \mu \mathrm{M})$ could block cell firings in $\sim 50 \%$ of the DRG cells isolated from control and CFA rats. In the other $50 \%$ of the cells tested, TTX had little effect on the spike generation. The ATP-evoked depolarizations in TTX-sensitive and -resistant neurons were evaluated separately. In TTX-sensitive neurons isolated from control rats (Fig. $7 A$, top), the average size of the depolarization was $12.4 \pm 3.7 \mathrm{mV}(n=4)$ before TTX and $11.8 \pm$ $4.1 \mathrm{mV}(n=4)$ after TTX. To inactivate TTX-resistant $\mathrm{Na}^{+}$ channels that might also be present in these cells, an $8 \mathrm{sec}$ depolarized prepulse to -10 or $-15 \mathrm{mV}$ was applied before ATP application. ATP-evoked depolarization, after the prepulse, was $11.3 \pm 3.6 \mathrm{mV}(n=4)$. The sizes of depolarizations under the various experimental conditions were not significantly different. We then examined ATP-evoked depolarizations in neurons isolated from inflamed rats. ATP evoked cell firings in all of the TTX-sensitive inflamed neurons (Fig. 7A, bottom). The depolarization evoked by ATP was $30.9 \pm 1.4(n=6)$ with TTX and
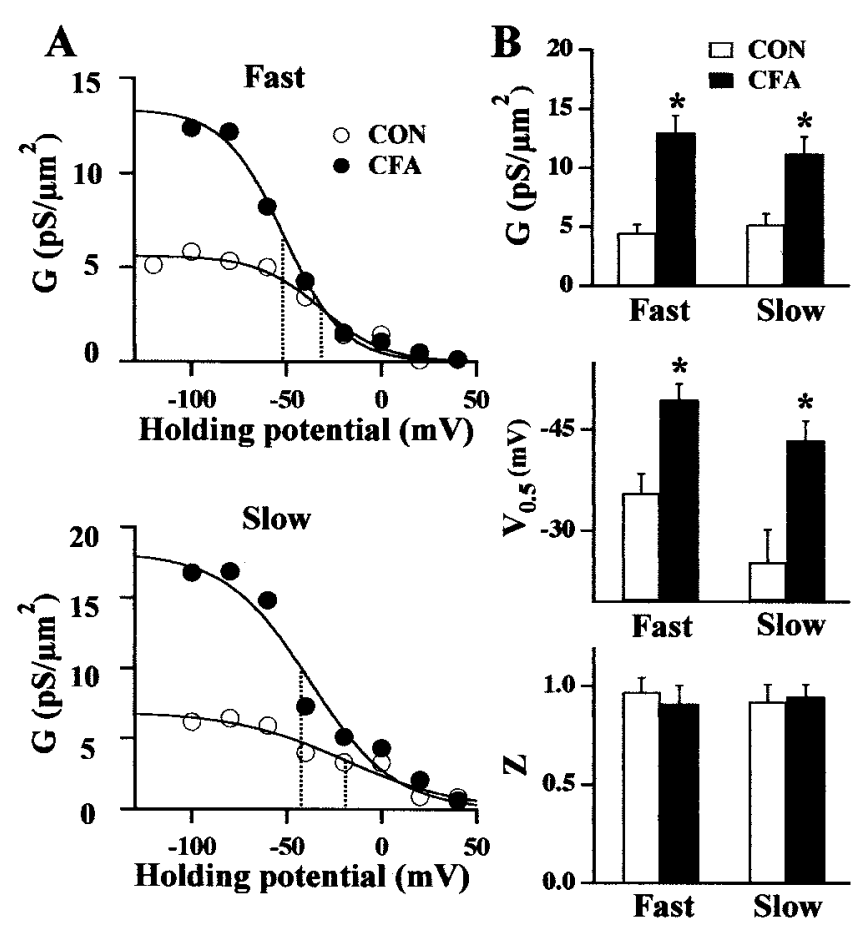

Figure 6. CFA alters the conductance-voltage curves. $A$, Examples of conductance-voltage $(G-V)$ curves. The data were calculated according to the procedure described in Materials and Methods, Data analyses. The solid lines were the theoretical fit of the Boltzmann equation using the following parameter values. Fast responses: control $(C O N), G_{\max }=5.6$ $\mathrm{pS} / \mu \mathrm{m}^{2}, Z=1.1$, and $V_{0.5}=-31.5 \mathrm{mV}$; CFA, $G_{\max }=13.4 \mathrm{pS} / \mu \mathrm{m}^{2}, Z=$ 1.2 , and $V_{0.5}=-51.4 \mathrm{mV}$. Slow responses: control, $G_{\max }=6.9 \mathrm{pS} / \mu \mathrm{m}^{2}$, $Z=0.9$, and $V_{0.5}=-19.0 \mathrm{mV} ; \mathrm{CFA}, G_{\max }=18.5 \mathrm{pS} / \mu \mathrm{m}^{2}, Z=1.1$, and $V_{0.5}=-39.0 \mathrm{mV}$. B, Mean parameters obtained from all of the cells tested. Fast responses: control, $G_{\max }=4.4 \pm 0.7 \mathrm{pS} / \mu \mathrm{m}^{2}, Z=0.97 \pm 0.07$, and $V_{0.5}=-35.6 \pm 2.9 \mathrm{mV}(n=10) ; \mathrm{CFA}, G_{\max }=12.9 \pm 1.4 \mathrm{pS} / \mu \mathrm{m}^{2}$, $Z=0.91 \pm 0.01$, and $V_{0.5}=-49.5 \pm 2.3 \mathrm{mV}(n=12)$. Slow responses: control, $G_{\max }=5.0 \pm 0.9 \mathrm{pS} / \mu \mathrm{m}^{2}, Z=0.92 \pm 0.09$, and $V_{0.5}=-25.4 \pm$ $4.8 \mathrm{mV}(n=6)$; CFA, $G_{\max }=11.0 \pm 0.1 \mathrm{pA} / \mu \mathrm{m}^{2}, Z=0.95 \pm 0.01$, and $V_{0.5}=-43.5 \pm 2.8 \mathrm{mV}(n=12)$. Inflammation increased $G_{\max }\left({ }^{*} p<0.05\right.$; top), shifted the $G-V$ curves in the hyperpolarized direction $\left({ }^{*} p<0.05\right.$; middle), and did not change the $Z$ ( $p>0.05$; bottom $)$.

$30.8 \pm 1.5 \mathrm{mV}(n=6)$ with both TTX and the prepulse. Thus, ATP evoked a substantially larger depolarization after inflammation (Fig. 7B).

The same experiments were repeated in TTX-resistant neurons. ATP did not evoke cell firings in most TTX-resistant neurons isolated from control rats (Fig. 7C, top). The average ATP-evoked depolarization in these cells was $15.7 \pm 1.6 \mathrm{mV}(n=$ 4) before TTX and $15.9 \pm 1.7 \mathrm{mV}(n=4)$ after TTX. When a depolarized prepulse was applied to this cell group, action potentials were often evoked at the beginning of the prepulse, even in the presence of TTX. The firing then subsided as the TTXresistant $\mathrm{Na}^{+}$channels became inactivated during the prepulse. The depolarization evoked by ATP applied after the prepulse was $15.6 \pm 1.7 \mathrm{mV}(n=4)$. The contribution of $\mathrm{Na}^{+}$channel activation to ATP depolarization was not significant. ATP invariably evoked cell firing in responsive TTX-resistant neurons isolated from CFA-treated rats (Fig. 7B, bottom traces). These spikes could not be blocked by TTX but were inactivated by the depolarized prepulse. The average ATP-induced depolarization after the depolarized prepulse was $32.4 \pm 1.5 \mathrm{mV}(n=4)$, which again is much larger than that obtained in control neurons (Fig. 7D).

We then examined threshold voltages of action potentials in 


\section{A TTX-Sensitive}
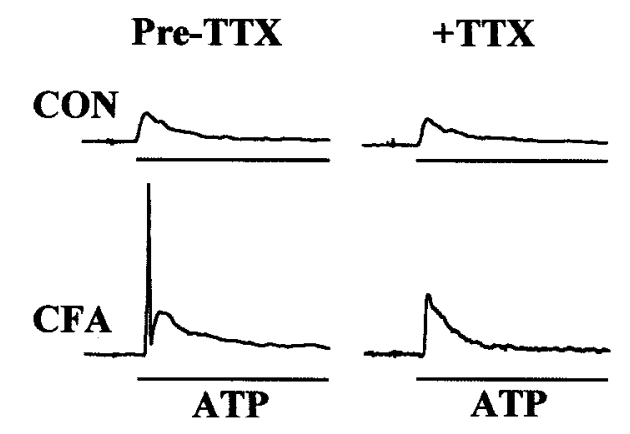

C TTX-Resistent
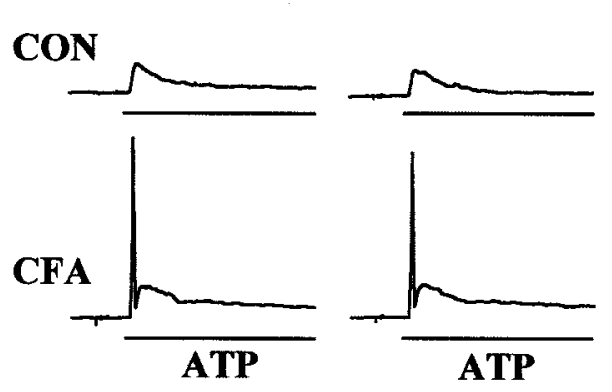

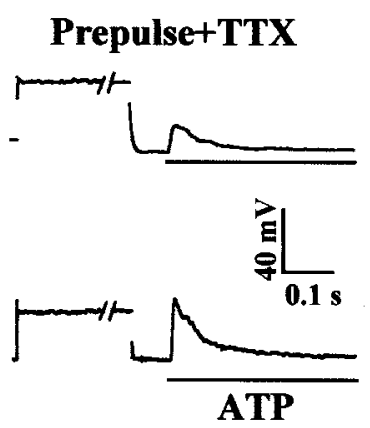

B

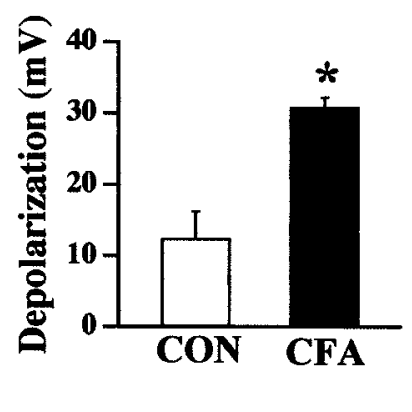

D
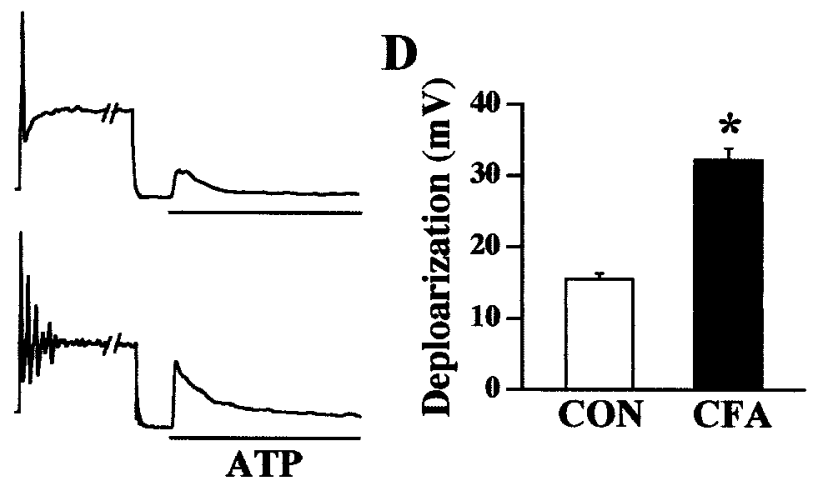

Figure 7. Inflammation increases ATP-evoked depolarizations in DRG cells. $A$, ATP-evoked depolarizations in TTX-sensitive neurons. Top, In control neurons $(C O N)$, ATP $(20 \mu \mathrm{M})$ produced subthreshold depolarizations in most responsive cells. In the cell shown, ATP-evoked depolarization was 13.5 $\mathrm{mV}$ before TTX $(2 \mu \mathrm{M})$ and $13.3 \mathrm{mV}$ after TTX. To inactivate TTX-resistant Na channels, a prepulse depolarized to $-15 \mathrm{mV}$ for a period of 8 sec was applied before the application of ATP. With the prepulse, ATP produced a $12.6 \mathrm{mV}$ depolarization. Resting potential was - $49 \mathrm{mV}$. Bottom, In the CFA neuron, ATP evoked an action potential that was blocked by TTX. In the presence of TTX, ATP evoked a depolarization of $36.0 \mathrm{mV}$ without the prepulse and $36.2 \mathrm{mV}$ with the prepulse. Resting potential was $-48 \mathrm{mV}$. Solid lines under current traces indicate the period of ATP applications. $B$, A bar graph summarizes the data obtained from TTX-sensitive neurons isolated from control and CFA rats. The average ATP-evoked depolarization was $12.4 \pm 3.7 \mathrm{mV}(n=4)$ in control and $30.8 \pm 1.5 \mathrm{mV}(n=6)$ in CFA neurons with both TTX and the prepulse. $C$, ATP-evoked depolarizations in TTX-resistant neurons. Top, In a control neuron, ATP evoked subthreshold depolarizations of $15.2 \mathrm{mV}$ before TTX and of $14.1 \mathrm{mV}$ after TTX. In the presence of TTX, the depolarized prepulse elicited an action potential that subsided as TTX-resistant channels inactivated. ATP after the prepulse produced a $13.5 \mathrm{mV}$ depolarization. Resting potential was $-53 \mathrm{mV}$. Bottom, After inflammation, ATP evoked an action potential that was insensitive to TTX. With the prepulse, ATP evoked $36.9 \mathrm{mV}$ depolarization in this cell. Resting potential was $-52 \mathrm{mV}$. $D$, The average depolarization produced by ATP in CFA neurons $(32.4 \pm 1.5 \mathrm{mV})$ was significantly larger than that produced in control neurons $(15.6 \pm 1.7 \mathrm{mV})$. Data were obtained from four different neurons. ${ }^{*} p<0.01$.

both control and inflamed neurons. The threshold voltage was $-24 \pm 2.4 \mathrm{mV}(n=9)$ in control neurons and $-25.5 \pm 1.3 \mathrm{mV}$ $(n=25)$ in inflamed neurons. CFA treatment did not change the threshold voltage significantly. Thus, in both TTX-sensitive and -resistant neurons isolated from control rats, ATP-evoked depolarizations are subthreshold. In contrast, ATP evokeddepolarizations in both types of neurons isolated from CFA rats are large and exceed the firing threshold of the neurons.

\section{Enhanced P2X receptor expression}

To determine whether the expression of $\mathrm{P} 2 \mathrm{X}$ receptors indeed increases in DRG after inflammation, Western blotting assays were performed on DRGs in control rats and in inflamed rats ipsilateral to the CFA-injected paw. Proteins were isolated from L4-L6 DRGs of control rats and rats treated with CFA for $5 \mathrm{~d}$. After separating the proteins by electrophoresis under denaturing conditions, they were transferred to nylon membranes and probed with anti-P2X2 and anti-P2X3. Anti-P2X2 antibody labeled a $\sim 64$ $\mathrm{kDa}$ molecular weight protein, and anti-P2X3 labeled a $\sim 57 \mathrm{kDa}$ protein. After CFA treatment, the molecular weight of the proteins did not change. However, the level of expression of both P2X2 and P2X3 receptors was increased significantly (Fig. 8)
$(\mathrm{P} 2 \mathrm{X} 2, \mathrm{CFA} /$ control $=1.81 ; \mathrm{P} 2 \mathrm{X} 3, \mathrm{CFA} /$ control $=1.82)$. Thus, inflammation upregulates the $\mathrm{P} 2 \mathrm{X} 2$ and $\mathrm{P} 2 \mathrm{X} 3$ receptor expression in DRGs.

\section{DISCUSSION}

We show here that ATP responses in DRG neurons are altered by inflammation. The most prominent change is a twofold to threefold increase in the current density of both fast and slow ATP responses (Fig. 1). Because the $\mathrm{EC}_{50}$ of the dose-response curve for ATP does not change in inflamed neurons (Fig. 4), the increase cannot be attributed to an increase in the affinity of ATP for its receptors. Possible mechanisms for the potentiation of ATP currents include an increase in single-channel conductance, enhancement of channel opening probability, and/or upregulation of $\mathrm{P} 2 \mathrm{X}$ receptor expression. Although single ATP receptor channel properties in inflamed neurons have yet to be studied, an increase in the opening probability of ATP channels is not likely because the kinetic properties of both fast and slow ATP currents remain unchanged after CFA treatment (Table 1). Because CFA produces a significant increase in $\mathrm{P} 2 \mathrm{X} 2$ and $\mathrm{P} 2 \mathrm{X} 3$ proteins (Fig. 8 ), upregulation of $\mathrm{P} 2 \mathrm{X}$ receptor expression is a major cause for 
$\mathbf{A}$

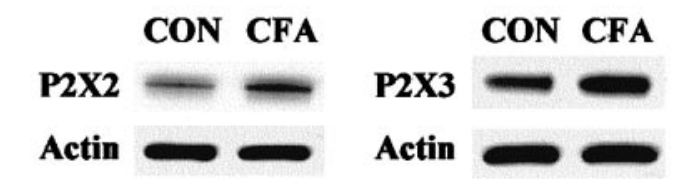

B

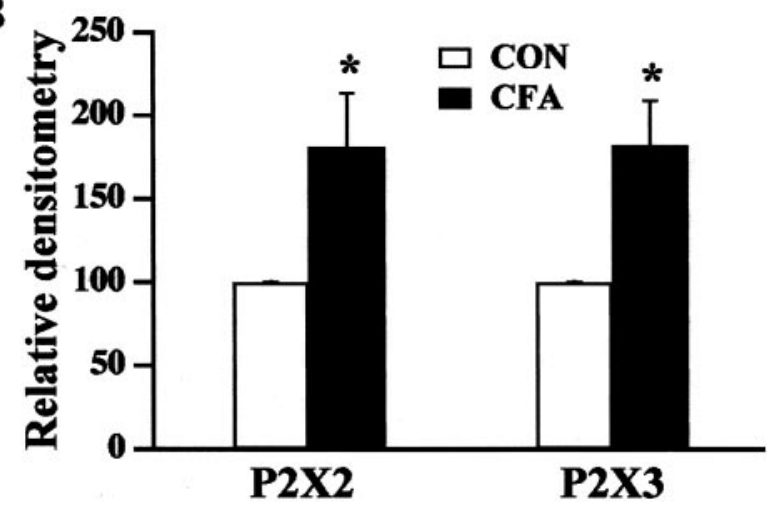

Figure 8. CFA treatment enhances $\mathrm{P} 2 \mathrm{X} 2$ and $\mathrm{P} 2 \mathrm{X} 3$ receptor expression. $A$, Western blots for $\mathrm{P} 2 \mathrm{X} 2$ and $\mathrm{P} 2 \mathrm{X} 3$ receptors from ganglia of control rats $(C O N)$ and rats $5 \mathrm{~d}$ after CFA treatment. Actin control for each sample was given. $B$, Mean density relative to control rats for P2X2 and $\mathrm{P} 2 \mathrm{X} 3$ receptors. After inflammation, the relative density of $\mathrm{P} 2 \mathrm{X} 2$ and P2X3 receptors were increased by 81 and $82 \%$, respectively $(n=3-5$ rats; ${ }^{*} p<0.05 ;$ Student's $t$ test $)$.

the large increase in ATP responses after the development of inflammation.

The current-voltage curves of both slow and fast ATP-evoked currents show inward rectification in control and CFA-treated rats (Fig. 5). The steepness of the rectification is similar to those reported by others in normal rats (Krishtal et al., 1983, 1988). The inward rectification characteristics of ATP responses are thought to arise from voltage-dependent blocking of intracellular cations (Krishtal et al., 1988) and/or fast voltage-dependent gating of ATP-activated channels (Bean, 1990; Bean et al., 1990). Our analyses of the voltage dependence of ATP responses show that the $G-V$ curves of both fast and slow ATP responses shift in the hyperpolarized direction after inflammation (Fig. 6). The mean $V_{0.5}$ of fast ATP current shifts from -35.6 to $-49.5 \mathrm{mV}$; the mean $V_{0.5}$ of slow responses shifts from -25.4 to $-43.5 \mathrm{mV}$. The mechanism underlying the shift is yet unclear. Changes in the phosphorylating state of $\mathrm{P} 2 \mathrm{X}$ receptors after inflammation could be a contributing factor (Paukert et al., 2001). One physiological consequence of the inward rectification of ATP currents is regulation of action potential generation. A large inward ATP current generated below the firing threshold (less than $-25 \mathrm{mV}$ ) will depolarize cells quickly and thus activate voltage-dependent ion channels. As the membrane potential depolarizes, the inward ATP current will get smaller. When the membrane potential becomes positive, the outward ATP current is nearly blocked. Thus, activation of $\mathrm{P} 2 \mathrm{X}$ receptors will facilitate the generation of action potential without shunting it at positive potentials. When the $G-V$ curves of ATP responses shift to hyperpolarized potentials after CFA treatment, the depolarizing effects of $\mathrm{P} 2 \mathrm{X}$ receptor activation would be dampened because a smaller fraction of $\mathrm{P} 2 \mathrm{X}$ receptors are activated at the resting potential. In our case, the relative conductance $\left(G / G_{\text {max }}\right)$ of the fast ATP response at $-50 \mathrm{mV}$ is 0.59 in control cells but becomes 0.51 in CFA neurons. A 2.9-fold increase in $G_{\max }$ after the development of inflamma- tion would give a 2.5 -fold increase in conductance at $-50 \mathrm{mV}$. Thus, despite curtailing the conductance increase by the leftward shift of the $G-V$ curve, the increase in conductance in inflamed neurons is still large.

We also compared the ATP-induced depolarizations in control and CFA neurons. To eliminate the contribution of depolarizations attributable to activation of voltage-dependent $\mathrm{Na}$ channels, TTX and a depolarized prepulse are used to block and inactivate Na channels (Ogata and Tatebayashi, 1993; Rush et al., 1998). Under such conditions, we found that, in contrast to ATPinduced subthreshold depolarizations in control neurons, ATP evokes large $(>30 \mathrm{mV})$ depolarizations that exceed the action potential threshold. The suprathreshold depolarization induced by ATP after inflammation is compelling evidence that upregulation of $\mathrm{P} 2 \mathrm{X}$ receptors may lead to enhanced firing activity in inflamed neurons.

Different types of sensory neurons have been shown to process distinct pain signals from the periphery to the spinal cord (Willis and Coggeshall, 1991). High percentages of cells are found to respond to ATP in in vitro studies of $\mathrm{P} 2 \mathrm{X}$ receptors in normal DRGs (Fig. 2) (Krishtal et al., 1988; Bean, 1990; Burgard et al., 1999; Grubb and Evans, 1999). Inflammation does not change the percentage of total cells responding to ATP (control, 89.4\%; CFA, 93.8\%), nor does it change the percentage of cells exhibiting fast and slow ATP currents (Fig. $2 A$ ). Because of the same pharmacological profiles of ATP responses between control and inflamed neurons (Fig. 3), P2X receptor phenotypes expressed in DRGs are not altered by inflammation. Thus, the homomeric P2X3 receptors are likely to mediate the fast-inactivating ATP currents and heteromeric $\mathrm{P} 2 \mathrm{X} 2 / 3$ receptors are likely to mediate the slow-inactivating ATP currents in inflamed neurons. We and others also show that, in normal rats, the diameters of cells responding to ATP with fast responses are in general smaller than those of cells responding to ATP with slow responses (Fig. 2B) (Tsuda et al., 1999, 2000; Ueno et al., 1999). Behavioral studies suggest that fast-desensitizing ATP responses from small capsaicin-sensitive neurons signal heat and nocifensive behaviors, and slow-desensitizing ATP responses from medium capsaicininsensitive neurons signal mechanical allodynia (Tsuda et al., 2000). Because the cell size distribution for fast or slow ATP responses remains unchanged after CFA treatment (Fig. 2B), various pain signals are likely to be processed differentially by homomeric $\mathrm{P} 2 \mathrm{X} 3$ and heteromeric $\mathrm{P} 2 \mathrm{X} 2 / 3$ receptors in distinct populations of inflamed DRG neurons.

All of our studies were conducted in the somata of DRGs in vitro. The roles of $\mathrm{P} 2 \mathrm{X}$ receptors on peripheral and central terminals in nociception are therefore inferred. Although the percentage of cells responding to ATP in intact DRG of control rats is much lower (Stebbing et al., 1998), it seems reasonable to assume that upregulation of $\mathrm{P} 2 \mathrm{X}$ receptors in the soma would lead to an increase in $\mathrm{P} 2 \mathrm{X}$ receptor expression at both terminals. Activation of $\mathrm{P} 2 \mathrm{X}$ receptors at central terminals has been shown to enhance the release of glutamate at synapses in the spinal cord (Li and Perl, 1995; Labrakakis et al., 2000; Nakatsuka and Gu, 2001). The proposed mechanisms underlying the synaptic action of $\mathrm{P} 2 \mathrm{X}$ receptor include $\mathrm{Ca}^{2+}$ influx through activated $\mathrm{P} 2 \mathrm{X}$ receptors (Robertson et al., 2001) and activation of voltagedependent $\mathrm{Ca}^{2+}$ channels activated by $\mathrm{P} 2 \mathrm{X}$ receptor-evoked action potentials (Cook and McCleskey, 1997; Gu and MacDermott, 1997). Our results suggest that ATP-evoked action potential generation is not likely to occur in control neurons. However, it may underlie the action of $\mathrm{P} 2 \mathrm{X}$ receptors in inflamed neurons 
(Fig. 7). In addition to activation of $\mathrm{P} 2 \mathrm{X}$ receptors, ATP is rapidly metabolized to adenosine during its release (Li and Perl, 1995; Nakatsuka and Gu, 2001; Robertson et al., 2001). Subsequent activation of $\mathrm{A} 1$ receptors by adenosine is found to inhibit the release of glutamate from central terminals of DRG neurons ( $\mathrm{Li}$ and Perl, 1994). Therefore, P2X and adenosine receptors exert opposite effects at glutamatergic synapses in the spinal dorsal horn. An increase in $\mathrm{P} 2 \mathrm{X}$ receptor expression at central terminals in the inflammatory state would increase the influence of $\mathrm{P} 2 \mathrm{X}$ receptor-mediated responses, thus potentiating the synaptic transmission in the dorsal horn. This possibility is consistent with the observation that intrathecally applied $\mathrm{P} 2 \mathrm{X}$ receptor antagonists become more effective in blocking $\mathrm{C}$-fiber-evoked responses in dorsal horn neurons after inflammation (Stanfa et al., 2000).

Peripheral P2X receptors at peripheral terminals are known to participate in the transmission of nociceptive and non-nociceptive responses (Cockayne et al., 2000; Hamilton and McMahon, 2000; Hamilton et al., 2000, 2001; Souslova et al., 2000; Tsuda et al., 2000). An increased ATP-evoked depolarization as the result of enhanced $\mathrm{P} 2 \mathrm{X}$ receptor expression at peripheral terminals could result in sensitization in sensory afferents. This possibility is consistent with the recent studies of pain behaviors in rats. The concentrations of ATP and $\alpha \beta$ meATP used in the behavioral studies in normal rats are $\geq 100 \mathrm{nmol}$, a range that is too high to be attained endogenously (Hamilton et al., 1999; Tsuda et al., 2000). After inflammation, ATP concentrations required to elicit pain behaviors are reduced 100-fold (Hamilton et al., 1999). The proposed mechanisms for the increase in the ATP effectiveness in nociceptive signaling include large leakage of ATP from injured cells, sensitization of $\mathrm{P} 2 \mathrm{X}$ receptors elicited by enhanced release of neuropeptides or $\mathrm{H}^{+}$from inflamed tissue, and changes in the second-messenger levels (Hamilton et al., 1999, 2001; Paukert et al., 2001). Although these possibilities cannot be dismissed, our results suggest that upregulation of $\mathrm{P} 2 \mathrm{X}$ receptors and enhanced ATP responses are the primary reasons for increased behavioral sensitivity in the inflammatory state. With a twofold to threefold increase in ATP responses after inflammation, a small amount of ATP release would evoke depolarizations large enough to elicit action potentials in DRG neurons (Fig. 7). It is therefore conceivable that endogenous ATP release does not produce pain in normal rats. The same ATP release after inflammation, however, will sensitize neurons and produce abnormal nociceptive responses. Therefore, the profound changes in $\mathrm{P} 2 \mathrm{X} 3$ and $\mathrm{P} 2 \mathrm{X} 2 / 3$ receptor expression and in ATP responses observed here may be critical for the induction of pain hypersensitivity after the development of inflammation.

\section{REFERENCES}

Bardoni R, Goldstein PA, Lee CJ, Gu JG, MacDermott AB (1997) ATP $\mathrm{P} 2 \mathrm{X}$ receptors mediate fast synaptic transmission in the dorsal horn of the rat spinal cord. J Neurosci 17:5297-5304.

Bean BP (1990) ATP-activated channels in rat and bullfrog sensory neurons: concentration dependence and kinetics. J Neurosci 10:1-10.

Bean BP, Williams CA, Ceelen PW (1990) ATP-activated channels in rat and bullfrog sensory neurons: current-voltage relation and singlechannel behavior. J Neurosci 10:11-19.

Bradbury EJ, Burnstock G, McMahon SB (1998) The expression of P2X3 purinoreceptors in sensory neurons: effects of axotomy and glial-derived neurotrophic factor. Mol Cell Neurosci 12:256-268.

Burgard EC, Niforatos W, van Biesen T, Lynch KJ, Touma E, Metzger RE, Kowaluk EA, Jarvis MF (1999) P2X receptor-mediated ionic currents in dorsal root ganglion neurons. J Neurophysiol 82:1590-1598.

Burnstock G (2001) Purine-mediated signalling in pain and visceral perception. Trends Pharmacol Sci 22:182-188.

Chen CC, Akopian AN, Sivilotti L, Colquhoun D, Burnstock G, Wood JN (1995) A P2X purinoceptor expressed by a subset of sensory neurons. Nature 377:428-431.
Cockayne DA, Hamilton SG, Zhu QM, Dunn PM, Zhong Y, Novakovic S, Malmberg AB, Cain G, Berson A, Kassotakis L, Hedley L, Lachnit WG, Burnstock G, McMahon SB, Ford AP (2000) Urinary bladder hyporeflexia and reduced pain-related behaviour in P2X3-deficient mice. Nature 407:1011-1015.

Cook SP, McCleskey EW (1997) Desensitization, recovery and $\mathrm{Ca}^{2+}$ dependent modulation of ATP-gated P2X receptors in nociceptors. Neuropharmacology 36:1303-1308.

Cook SP, McCleskey EW (2000) ATP, pain, a full bladder. Nature 407:951-952.

Cook SP, Vulchanova L, Hargreaves KM, Elde R, McCleskey EW (1997) Distinct ATP receptors on pain-sensing and stretch-sensing neurons. Nature 387:505-508.

Dilger JP, Brett RS (1990) Direct measurement of the concentrationand time-dependent open probability of the nicotinic acetylcholine receptor channel. Biophys J 57:723-731.

Gold MS (1999) Tetrodotoxin-resistant $\mathrm{Na}^{+}$currents and inflammatory hyperalgesia. Proc Natl Acad Sci USA 96:7645-7649.

Gould III HJ, England JD, Liu ZP, Levinson SR (1998) Rapid sodium channel augmentation in response to inflammation induced by complete Freund's adjuvant. Brain Res 802:69-74.

Grubb BD, Evans RJ (1999) Characterization of cultured dorsal root ganglion neuron P2X receptors. Eur J Neurosci 11:149-154.

Gu JG, MacDermott AB (1997) Activation of ATP P2X receptors elicits glutamate release from sensory neuron synapses. Nature 389:749-753.

Gu YP, Huang LYM (2001) Gabapentin actions on $N$-methyl-D-aspartate receptor channels are protein kinase C-dependent. Pain 93:85-92.

Hamilton S, McMahon S, Lewin G (2001) Selective activation of nociceptors by $\mathrm{P} 2 \mathrm{X}$ receptor agonists in normal and inflamed rat skin. J Physiol (Lond) 534:437-445.

Hamilton SG, McMahon SB (2000) ATP as a peripheral mediator of pain. J Auton Nerv Syst 81:187-194.

Hamilton SG, Wade A, McMahon SB (1999) The effects of inflammation and inflammatory mediators on nociceptive behaviour induced by ATP analogues in the rat. Br J Pharmacol 126:326-332.

Hamilton SG, Warburton J, Bhattacharjee A, Ward J, McMahon SB (2000) ATP in human skin elicits a dose-related pain response which is potentiated under conditions of hyperalgesia. Brain 123:1238-1246.

Jahr CE, Jessell TM (1983) ATP excites a subpopulation of rat dorsal horn neurones. Nature 304:730-733.

Kanjhan R, Housley GD, Burton LD, Christie DL, Kippenberger A, Thorne PR, Luo L, Ryan AF (1999) Distribution of the P2X2 receptor subunit of the ATP-gated ion channels in the rat central nervous system. J Comp Neurol 407:11-32.

Krishtal OA, Marchenko SM, Pidoplichko VI (1983) Receptor for ATP in the membrane of mammalian sensory neurones. Neurosci Lett 35:41-45.

Krishtal OA, Marchenko SM, Obukhov AG (1988) Cationic channels activated by extracellular ATP in rat sensory neurons. Neuroscience 27:995-1000.

Labrakakis C, Gerstner E, MacDermott AB (2000) Adenosine triphosphate-evoked currents in cultured dorsal root ganglion neurons obtained from rat embryos: desensitization kinetics and modulation of glutamate release. Neuroscience 101:1117-1126.

Lewis C, Neidhart S, Holy C, North RA, Buell G, Surprenant A (1995) Coexpression of $\mathrm{P} 2 \mathrm{X} 2$ and $\mathrm{P} 2 \mathrm{X} 3$ receptor subunits can account for ATP-gated currents in sensory neurons. Nature 377:432-435.

Li J, Perl ER (1994) Adenosine inhibition of synaptic transmission in the substantia gelatinosa. J Neurophysiol 72:1611-1621.

Li J, Perl ER (1995) ATP modulation of synaptic transmission in the spinal substantia gelatinosa. J Neurosci 15:3357-3365.

Li P, Calejesan AA, Zhuo M (1998) ATP P2x receptors and sensory synaptic transmission between primary afferent fibers and spinal dorsal horn neurons in rats. J Neurophysiol 80:3356-3360.

Nakatsuka T, Gu JG (2001) ATP P2X receptor-mediated enhancement of glutamate release and evoked EPSCs in dorsal horn neurons of the rat spinal cord. J Neurosci 21:6522-6531.

North RA, Barnard EA (1997) Nucleotide receptors. Curr Opin Neurobiol 7:346-357.

North RA, Surprenant A (2000) Pharmacology of cloned P2X receptors Annu Rev Pharmacol Toxicol 40:563-580.

Ogata N, Tatebayashi H (1993) Kinetic analysis of two types of $\mathrm{Na}^{+}$ channels in rat dorsal root ganglia. J Physiol (Lond) 466:9-37.

Paukert M, Osteroth R, Geisler HS, Brandle U, Glowatzki E, Ruppersberg JP, Grunder S (2001) Inflammatory mediators potentiate ATPgated channels through the $\mathrm{P} 2 \mathrm{X}(3)$ subunit. J Biol Chem 276:21077-21082

Robertson SJ, Ennion SJ, Evans RJ, Edwards FA (2001) Synaptic P2X receptors. Curr Opin Neurobiol 11:378-386.

Rush AM, Brau ME, Elliott AA, Elliott JR (1998) Electrophysiological properties of sodium current subtypes in small cells from adult rat dorsal root ganglia. J Physiol (Lond) 511:771-789.

Souslova V, Cesare P, Ding Y, Akopian AN, Stanfa L, Suzuki R, Carpenter K, Dickenson A, Boyce S, Hill R, Nebenuis-Oosthuizen D, Smith AJ, Kidd EJ, Wood JN (2000) Warm-coding deficits and aber- 
rant inflammatory pain in mice lacking $\mathrm{P} 2 \mathrm{X} 3$ receptors. Nature 407:1015-1017.

Stanfa LC, Kontinen VK, Dickenson AH (2000) Effects of spinally administered $\mathrm{P} 2 \mathrm{X}$ receptor agonists and antagonists on the responses of dorsal horn neurones recorded in normal, carrageenan-inflamed and neuropathic rats. Br J Pharmacol 129:351-359.

Stebbing MJ, McLachlan EM, Sah P (1998) Are there functional P2X receptors on cell bodies in intact dorsal root ganglia of rats? Neuroscience 86:1235-1244.

Thomas S, Virginio C, North RA, Surprenant A (1998) The antagonist trinitrophenyl-ATP reveals co-existence of distinct $\mathrm{P} 2 \mathrm{X}$ receptor channels in rat nodose neurones. J Physiol (Lond) 509:411-417.

Tsuda M, Ueno S, Inoue K (1999) In vivo pathway of thermal hyperalgesia by intrathecal administration of alpha,beta-methylene ATP in mouse spinal cord: involvement of the glutamate-NMDA receptor system. Br J Pharmacol 127:449-456.

Tsuda M, Koizumi S, Kita A, Shigemoto Y, Ueno S, Inoue K (2000) Mechanical allodynia caused by intraplantar injection of $\mathrm{P} 2 \mathrm{X}$ receptor agonist in rats: involvement of heteromeric $\mathrm{P} 2 \mathrm{X} 2 / 3$ receptor signaling in capsaicin-insensitive primary afferent neurons. J Neurosci 20:1-5.

Ueno S, Tsuda M, Iwanaga T, Inoue K (1999) Cell type-specific ATPactivated responses in rat dorsal root ganglion neurons. Br J Pharmacol 126:429-436.

Virginio C, Robertson G, Surprenant A, North RA (1998) Trinitro- phenyl-substituted nucleotides are potent antagonists selective for $\mathrm{P} 2 \mathrm{X} 1, \mathrm{P} 2 \mathrm{X} 3$, and heteromeric $\mathrm{P} 2 \mathrm{X} 2 / 3$ receptors. Mol Pharmacol 53:969-973.

Vulchanova L, Riedl MS, Shuster SJ, Buell G, Surprenant A, North RA Elde R (1997) Immunohistochemical study of the P2X2 and P2X3 receptor subunits in rat and monkey sensory neurons and their central terminals. Neuropharmacology 36:1229-1242.

Vulchanova L, Riedl MS, Shuster SJ, Stone LS, Hargreaves KM, Buell G, Surprenant A, North RA, Elde R (1998) P2X3 is expressed by DRG neurons that terminate in inner lamina II. Eur $J$ Neurosci 10:3470-3478.

Willis WD, Coggeshall R (1991) Dorsal root ganglion cells and their processes. In: Sensory mechanisms of the spinal cord, Ed 2, pp 47-78. New York: Plenum.

Woolf CJ, Doubell TP (1994) The pathophysiology of chronic painincreased sensitivity to low threshold A beta-fibre inputs. Curr Opin Neurobiol 4:525-534.

Xu GY, Huang LYM (1999) Peripheral inflammation potentiates P2Xreceptor mediated responses in rat dorsal root ganglion neurons. Soc Neurosci Abstr 25:459.

Xu GY, Huang LY, Zhao ZQ (2000) Activation of silent mechanoreceptive cat $\mathrm{C}$ and $\mathrm{A}$ delta sensory neurons and their substance $\mathrm{P}$ expression following peripheral inflammation. J Physiol (Lond) 528: 339-348. 